\title{
Australian Journal of
}

\section{Emergency Management}

\section{Copyright release}

\section{Enquiries}

P: +61 394192388

E: ajem editor@aidr.org.au

W: knowledge.aidr.org.au

All articles submitted to the Australian Journal of Emergency Management, must include a copy of this document, filled in and signed by all authors.

\section{Non-exclusive licence}

(the 'Article') is herewith submitted for publication in the Australian Journal of Emergency Management (AJEM).

I (We), as author(s) ('Author') hereby grant to the National Emergency Management Agency (NEMA) a perpetual, irrevocable, royalty-free, world-wide, non-exclusive licence to:

a. Publish, use, communicate, adapt and reproduce the Article in whole or in part, including print, electronic and digital forms, provided that the Author's copyright in the Article is acknowledged.

b. Create adaptions, summaries or extracts of the Article or other derivative works based on the Article.

c. Send abstracts and complete versions of the Article to any person or organisation for further publication.

d. Sub-licence all such rights to others.

\section{Publisher}

The Australian Journal of Emergency Management is published by the Australian Institute for Disaster Resilience with financial assistance from NEMA. The journal is published online at www.knowledge.aidr.org.au.

\section{Publication policy}

All Articles in AJEM are published under a Creative Commons Attribution Non Commercial (CC BY-NC 4.0) licence that allows reuse, subject only to the use being non-commercial and to the Article being fully attributed (http://creativecommons. org/licenses/by-nc/4.0). AIDR makes all AJEM Articles freely available on the Australian Disaster Resilience Knowledge Hub from the date of publication. The Creative Commons copyright statement appears in AJEM, and as a footnote at the end of individual downloadable Articles in the following form:

"This is an open access Article distributed in accordance with the Creative Commons Attribution Non Commercial (CC BY-NC 4.0) license, which permits others to distribute, remix, adapt, build upon this work non-commercially, and license their derivative works on different terms, provided the original work is properly cited and the use is non-commercial. See: http://creativecommons.org/licenses/by-nc/4.0."

\section{Acknowledgements by Author}

The Author acknowledges that NEMA has the right to edit the submitted Article in accordance with the Australian Government Style Manual or any other style manual determined by AIDR. Substantial content edits will be referred to the Author before publication.

\section{Warranties}

The Author warrants that:

a. The Author is the sole owner of the Article and has ful right and title to copyright in the Article.

b. The Article is not copied wholly or substantially from any other work or material.

c. The Author has not entered into any agreement or arrangement involving the sale, mortgage, pledge, granting of options or any other rights over their interest in the copyright in the Article.

d. The mere use and exercise of copyright in the Article by NEMA or any licensee or sub-licensee of NEMA will not infringe any copyright or similar or other intellectual property rights of any person, nor give rise to payment by NEMA or any licensee or sub-licensee of NEMA or any royalty to any third party or to any liability to pay compensation.

e. Neither the execution of the Agreement nor the performance by the Author of their obligations will cause the Author to be in breach of any agreement to which Author is a party or is subject. 


\title{
Australian Journal of
}

\section{Emergency Management}

\section{Copyright release}

\author{
Enquiries \\ P: +61 394192388 \\ E: ajem editor@aidr.org.au \\ W: knowledge.aidr.org.au
}

All articles submitted to the Australian Journal of Emergency Management, must include a copy of this document, filled in and signed by all authors.

The Author indemnifies NEMA against any claim, loss, liability, cost or expense (including legal expenses on a solicitor and own party basis) which may be incurred or sustained by NEMA as a result of any breach of the warranties given in this Clause.

\section{Indemnity}

If NEMA or any licensee or sub-licensee of NEMA is required to make a payment by way of damages to a third party as a result of the Author breaching the copyright of the third party in the course of preparing the Article, the Author hereby agrees to indemnify NEMA or any licensee or sub-licensee of NEMA in full in respect of the amount paid by NEMA or any licensee or sub-licensee of NEMA to the third party, together with any costs incurred by NEMA or any licensee or sublicensee of NEMA.

\section{No prior representations}

This Agreement contains the entire agreement between the parties with respect to its subject matter and supersedes all prior agreements and understandings between the parties in connection with it.

This Agreement is to be read in conjunction with the AJEM Editorial Policy and forms the entire policy.

\section{Amendment}

No amendment or variation of this Agreement is valid or binding on a party unless made in writing and executed by all parties.

\section{Expiration of agreement}

If NEMA rejects the Article for publication or has not published the Article in the AJEM in accordance with this Agreement within twelve months after the date of this Agreement, all licences of rights to the NEMA as set out in this Agreement cease.

\section{Mutual obligation}

The Author will respond in a timely manner to editorial requests made by AJEM.

\section{Governing law}

The laws applicable in the Australian Capital Territory of Australia govern this Agreement and the parties irrevocably submit to the non-exclusive jurisdiction of the courts of that Territory.

Dated this day

\section{Signature}

Signature

Signature 